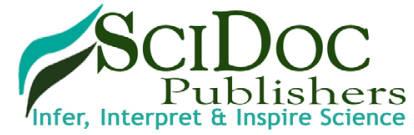

\section{Quality Evaluation of Millet-Based Fura Powder Supplemented with Bambara Groundnut}

Research Article

Adebayo-Oyetoro Abiodun $\mathrm{O}^{1 *}$, Shotunde $\mathrm{AB}^{1}$, Adeyeye Samuel $\mathrm{AO}^{2}$, Ogundipe $\mathrm{OO}^{1}$

${ }^{1}$ Yaba College of Technology, Department of Food Technology, P.M.B 2011, Yaba, Lagos State, Nigeria.

${ }^{2}$ Mountain Top University, Department of Food Science \&Technology, Prayer City, Ibafo, Ogun State, Nigeria.

\title{
Abstract
}

"Fura" is known to have originated from Hausa/Fulani and is produced mainly from most flour, blended with species, compressed into balls and boiled for thirty minutes, while still hot, the cooked dough is worked through in the mortar with the pestle(with addition of hot water), until a smooth, slightly elastic cohesive lump fura is formed. This study was carried out to improve the nutritional quality of fura, a millet-based flour food by adding bambara nut flour. Pearl millet (Pennisetumglaucum) and bambara groundnut (Vigna subterranean) were cleaned, dry milled and sieved to produced fura flour. The bambara groundnut flour was substituted into the pearl millet flour at ratio (0-30\%); and mixed with spices. This was conditioned using 1.5L of tap water to improve molding. The sample were analyzed for chemical, functional, microbial and sensory properties. The data obtained were analyzed using ANOVA $(\mathrm{p}<0.05)$. Results showed that carbohydrate, protein, crude fiber, water absorption, and viscosity ranged between, $75.53 \pm 0.08$ to $80.58 \pm 0.08,7.27 \pm 0.01$ to $7.85 \pm 0.01,0.23 \pm 0.01$ to $1.12 \pm 0.01,2.47 \pm 0.02$ to $0.89 \pm 0.02,493.00 \pm 4.24$ to $311.50 \pm 0.71$ while sensory evaluation showed that sample BYS was most acceptable. This study showed improvement in the qualities of fura enriched with bambara groundnut.

Keywords: Fura; Pasting Properties; Bambara Groundnut; Pearl Millet; Quality.

\section{Introduction}

Pearl millet (Pennisetum glaucum), also known as bajra, is a cereal crop grown in tropical semi-arid regions of the world primarily in Africa and Asia. Bajra is well adapted to production systems characterized by low rainfall (200-600 $\mathrm{mm}$ ), low soil fertility, and high temperature, and thus can be grown in areas where other cereal crops, such as wheat or maize, would not survive. In its traditional growing areas, pearl millet is the basic staple for households in the poorest countries and among the poorest people. It is also one of the most drought resistant crops among cereals and millets. Pearl millet is generally used as a temporary summer pasture crop or in some areas as a food crop. Pearl millet is one of the four most important cereals (rice, maize, sorghum and millets) grown in the tropics and is rich in iron and zinc which together with its high amount of antioxidants may be beneficial for the overall health and wellbeing NIN (2003).
Enrichment of cereal based food with other protein source such as legumes has received considerable attention. The use of cereallegume based food has long been advocated as alternative protein and energy source for infant and young children food products. It is evident that when cereals and legumes are judiciously selected and combine desirable pattern of essential amino acids of high biological value is obtained. Cereals are deficient in essential amino acid like lysine and tryptophan. Legumes are deficient in sulphur-containing amino acids like methionine and cysteine, but rich in tryptophan and lysine. Fura is solely a cereal-based food that will require the addition of a rich plant based protein source for enrichment. Addition of bambara groundnut to 'fura' will help to increase the protein quality and quantity as well as provide good quality essential fatty acids because bambara groundnut is a good source of protein and oil. It will also help to prevent the incidence of protein-energy malnutrition in children who consume this product.

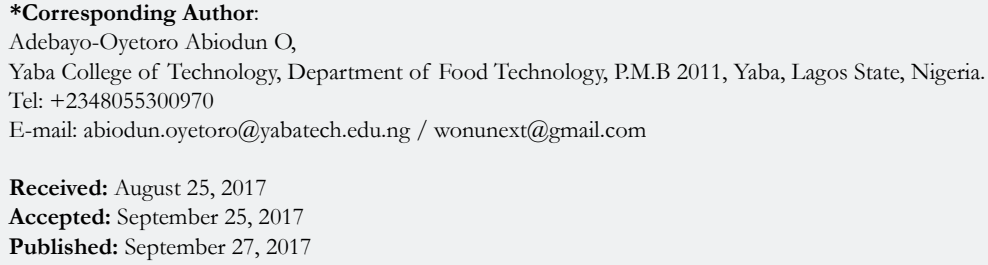

Citation: Adebayo-Oyetoro Abiodun O, Shotunde AB, Adeyeye Samuel AO, Ogundipe OO. Quality Evaluation of Millet-Based Fura Powder Supplemented with Bambara Groundnut. Int J Food Sci Nutr Diet. 2017;6(3):358-362. doi: http://dx.doi.org/10.19070/2326-3350-1700063

Copyright: Adebayo-Oyetoro Abiodun $\mathbf{O}^{\circ}$ 2017. This is an open-access article distributed under the terms of the Creative Commons Attribution License, which permits unrestricted use, distribution and reproduction in any medium, provided the original author and source are credited. 
Bambara groundnut (Voandzeia subterranean) is a legume crop native to Africa commonly grown for its seeds by subsistence farmers. It is grown in many parts of Africa, in parts of Asia, especially Indonesia, and South America $[9,11]$. Bambara groundnut is predominantly grown for human consumption and like groundnut the seeds are dug from the ground and then are usually boiled, fried or roasted for consumption. Alternatively, the seeds are ground into flour and blended into many customary dishes. Despite the almost total scientific neglect, the crop still makes a great contribution to the diet in many parts of Africa. In Zambia bambara groundnut is used for bread making (Brought et al., 1993 cited by Okpuzor et al., 2010) [15], and it could also be used to produce imitation milk (Poulter and Caygill, 2006 cited by Okpuzor et al., 2010) [15].

Wheat flour biscuits supplemented with bambara groundnut flour were shown to have improved flavor and texture [7]. Considering its nutritional composition, bambara groundnut is an uncommon example of a complete food and it has been supposedly believed that people can live on it alone. The ripe seed or immature beans contain about $20 \%$ protein, $60 \%$ carbohydrates and $7 \%$ oil. The legumes are important sources of dietary protein [8]. When compared to other food legumes, bambara groundnut is rich in iron and the protein contains high lysine (Adu and Sangwan, 2004 cited by Okpuzor et al., 2010) [15], and can thus complement cereals.

"Fura" is a semi-solid dumpling cereal meal produced mainly from moist pearl millet (Pennisettum glaucum) flour, blended with spices compressed into balls and boiled thirty (30) minutes, while still hot the cooked dough is worked through in the mortar with the pestle(with addition of hot water), until a smooth, slightly elastic cohesive lump fura is formed.

The aim of this study is to determine the effect of process modification and addition of bambara groundnut to the quality and sensory properties of fura.

\section{Materials and Methods}

Pearl millet (Pennisetum glaucum) and bambara groundnut (Vigna. subterranea) and other spices such as chili pepper (Capsicum annum), ginger (Zingiber officinale) and cloves were purchased from Ketu Market, Lagos, Nigeria.

The pearl millet grains were sorted and dry cleaned. The grains were dehulled after mild wetting of the grain prior to dehulling using traditional mortar and pestle. After dehulling, the grains were washed with tap water to remove the bran before drying in hot air oven at $100^{\circ} \mathrm{C}$ for 6 hours to about $12 \%$ moisture content. The dried grains were milled into flour using hammer mill.
The bambara groundnut seeds were steeped in tap water at $28^{\circ} \mathrm{C}$ for a period of $30 \mathrm{mins}$ to loosen the seed coat. The kernels were dehulled using traditional pestle and mortar. After dehulling, the grains were washed and the hulls removed. The grains were later dried in a hot air oven at $100^{\circ} \mathrm{C}$ for 6 hours to $12 \%$ moisture content and the mass was winnowed to remove the remaining lighter materials using an aspirator. The dehulled bambara groundnut kernels were milled into fine flour using hammer mill. The flour was sieved using a $150 \mu \mathrm{m}$ screen size.

\section{Production of fura}

The bambara groundnut flour was added into the fura flour (pearl millet flour) in a clean bowl, after which weighed spices (ginger, cloves, chili pepper) were added using the ratios shown in Table 1. These were thoroughly mixed manually followed by conditioning by adding $1.5 \mathrm{~L}$ of tap water to improve molding. The conditioned flours were weighed, molded into balls, steamed (15min), followed by pounding using the local mortar and pestle until a smooth and slightly elastic consistency was achieved. The smooth and elastic dough from various blends were remolded into balls and cooked again for $30 \mathrm{mins}$. The balls were cooled, broken into small pieces and dried in a cabinet dryer at $60^{\circ} \mathrm{C}$ for 1 hour to about $7 \%$ moisture. The dried fura samples were milled with a hammer mill to flours of particle sizes of about $322 \mu \mathrm{m}$ and packaged.

\section{Proximate Composition}

The moisture, protein, fat, ash and crude fiber content were determined according to AOAC (2005). Carbohydrate was determined by difference. Food energy (kcal/100g)was calculated according to the method of Marero et al., (1988) [10] using factors of :[(4x\% protein $)+(4 \mathrm{x} \%$ carbohydrate $)+(9 \mathrm{x} \%$ fat $)]$.

\section{Functional Properties}

Foaming capacity: Two gram of the sample and $50 \mathrm{ml}$ distilled water was mixed at room temperature. The suspension was stirred for $5 \mathrm{~min}$ at $1000 \mathrm{rpm}$. The total volume after 30 seconds was recorded. It was allowed to stand at room temperature for 30 minutes and the volume of foam recorded. The percentage increase in volume after 30 secs is expressed as foaming capacity. The height of the foam was determined by taking the reading.

Water Absorption Capacity: The procedure of Beuchart (1977) [4] was used to determine water absorption capacity (WAC). $1 \mathrm{~g}$ of the flour of the sample was mixed with $10 \mathrm{~cm}^{3}$ distilled water using a mixer for about 30 minutes at room temperature of $28^{\circ} \mathrm{C}$. The mixture was centrifuged for 30 minutes using a table Gallenkamp centrifuge at 3,500 rpm and the supernatant decanted

Table 1. Recipe formulation.

\begin{tabular}{|c|c|c|c|c|}
\hline Sample/ Ingredient & FMX & BYS & MKL & DST \\
\hline Fura flour (\%) & 100 & 90 & 80 & 70 \\
\hline Bambara nut flour $(\%)$ & 0 & 10 & 20 & 30 \\
\hline Ginger (g) & 1.34 & 1.34 & 1.34 & 1.34 \\
\hline Chilly pepper (g) & 0.50 & 0.50 & 0.50 & 0.50 \\
\hline Cloves (g) & 0.50 & 0.50 & 0.50 & 0.50 \\
\hline
\end{tabular}


into a $10 \mathrm{~cm}^{3}$ graduated measuring cylinder to obtain the amount of water remaining. The excess water absorbed by the sample was expressed as the percentage water bound by $100 \mathrm{~g}$ sample. Water density was assumed to be $1 \mathrm{~g} / \mathrm{cm}^{3}$.

Bulk Density: Fifty (50 g) flour sample was put into a $100 \mathrm{ml}$ measuring cylinder. The cylinder was tapped several times on a laboratory bench to a constant volume. The volume of sample is recorded.

Bulk density $(\mathrm{g} / \mathrm{cm})=$ Weight of Sample $(\mathrm{g} / \mathrm{cm}) /$ Volume of sample after tapping

\section{Sensory Evaluation}

Fifty gram (50g) of each sample was reconstituted into a sterile water to act as a binding agent to form a ball snacks, the balls was then placed in already boiled water for 20 minutes, it was then mashed in mortar and pestle and was formed into balls. The prepared samples were then evaluated for sensory parameters which include taste, aroma, color, mouth feel, and overall acceptability on a 9-point hedonic scale ranging from like extremely to dislike extremely. Twenty-man panel was used for the exercise. These panelists were selected among students both within and outside the department of Food Technology, Yaba College of Technology especially those who are familiar with the product. They gave three responses in numerical values and statistical analysis was carried out on the results.

\section{Statistical Analysis}

The results obtained were subjected to analysis of variance (ANOVA) and Duncan multiple range test [5] was used to separate means where significant differences existed.

\section{Results and Discussion}

The proximate and energy composition of fura flour enriched with bambara groundnut are shown in Table 2 . The moisture content of the millet-based fura decreased from 7.16 to $6.74 \%$, as the level of substitution increases. The increase in the moisture content is relatively low which could be an advantage in the keeping quality of the product as it will not allow the growth of spoilage microorganisms as well as biochemical and enzymatic reactions. The fat content increased from 2.68 - $8.39 \%$ with increase in the percentage of bambara groundnut flour. The increase in fat content could be due to the added bambara groundnut. The relative increase in fat content could improve the energy level of the consumer as it has been known that one gram of fat or oil will yield about $368 \mathrm{~kJ} / \mathrm{gkcal}$ of energy when oxidized in the body [13]. The energy values of the samples are similar to the findings of Adebayo-Oyetoro et al. (2013) [1]. Energy content is needed to determine the quality of food formulated for adults with high energy requirement.

The protein content increased from $7.27-7.85 \%$ with increase in the percentage $(0-30 \%)$ of bambara groundnut flour. The increase in the protein content could be due to the added bambara groundnut which have been confirmed to contain substantial high level of the protein and could be an inexpensive source of this nutrient [16]. Bambara nut is a rich source of protein. The ash content of the products increased from $0.86-1.62 \%$ with increased addition of bambara groundnut flour. The increase in the ash content could be due to the added bambara groundnut which have been noted to be relatively high in minerals. High ash content could be an indication of increase in the principal mineral content which could be of vital importance to the body [3].

Ash content indicates the presence of mineral matter in food. Ash is a non-organic compound containing the mineral content of food. It aids in the metabolism of other compound such as protein, fat and carbohydrates [13]. The crude fiber (\%) of the product increased from $0.23-1.12 \%$, as the percentage of added bambara groundnut flour increased. The increase in percentage fiber could be due to high fiber content of bambara groundnut. Relatively high fiber content could be an advantage in the ease of empty of bowel and prevention of arthritis.

Table 3 showed the functional properties of millet-based fura substituted with bambara nut. The bulk density increased with increase in percentage of bambara groundnut flour. Samples FMX and DST has the lowest and highest bulk density respectively. The increase in bulk density could be an advantage in packaging of the product as it will occupy less space and could also be advantage in solubility as the particles has less tendency of floating during soaking in liquid prior to consumption which could also improve digestion. The foaming capacity of the product increased from 8.06-15.12\% with increase in percentage (0-30\%) of added bambara groundnut flour. The increase in the foaming capacity could be due to high protein content of the added bambara groundnut. The high foaming capacity could be an advantage in the solubility of the product and also ability to incorporate air resulting in the raising of the product thereby giving the end product a honeycomb structure as desired in bread, cake and ice cream. The water absorption capacity deceased with increase in the added bambara groundnut flour $(0-30 \%)$. The decrease in the water absorption capacity could be due to the presence of the husk or outer coat of the bambara groundnut as a result of low extraction rate during processing. The presence of the hull (cellulose and hemi-cellulose) has been observed to have low water absorption capacity. Low water absorption could be an advantage in storage 'stability as the rate of absorption could be relatively low hence lower moisture availability for microbial growth and biochemical reactions.

The $\mathrm{pH}$ values ranged from 5.52-6.21 which makes it edible and safe for consumption. The results showed that sample FMX and DST had the lowest and highest $\mathrm{pH}$ values respectively which are close to neutral value of 7 . This $\mathrm{pH}$ range will hinder the growth of most spoilage organisms. The results of viscosity showed that, increasing the level of bambara groundnut flours marginally reduces the viscosities of flours as shown in table 4. FMX and DST had the highest and lowest values respectively.

Table 4 showed the results of sensory evaluation of millet-based fura supplemented with bambara nut samples. There were significant differences in all the attributes measured. The results for colour, taste, overall acceptance, aroma and mouth-feel follow the same trends which show a decrease in values as the ratio of bambara nut increased. The mean and standard deviation for colour were obtained as $7.15 \pm 1.08,7.08 \pm 1.11,6.47 \pm 0.84$ and 5.15 \pm 1.02 for FMX, BYS, MKL and DST respectively. Sample FMX 
Table 2. The proximate composition and energy value of fura flour enriched with bambara groundnut.

\begin{tabular}{|c|c|c|c|c|c|c|c|}
\hline & Moisture (\%) & Ash (\%) & Fat (\%) & $\begin{array}{c}\text { Crude fibre } \\
\mathbf{( \% )}\end{array}$ & $\begin{array}{c}\text { Protein } \\
\mathbf{( \% )}\end{array}$ & $\begin{array}{c}\text { Carbohydrate } \\
\mathbf{( \% )}\end{array}$ & $\begin{array}{c}\text { Energy } \\
\text { (Kcal/100g) }\end{array}$ \\
\hline FMX & $6.74 \pm 0.03^{\mathrm{a}}$ & $0.86 \pm 0.04^{\mathrm{d}}$ & $2.68 \pm 0.01^{\mathrm{d}}$ & $0.23 \pm 0.01^{\mathrm{c}}$ & $7.27 \pm 0.01^{\mathrm{c}}$ & $75.53 \pm 0.08^{\mathrm{d}}$ & 355.32 \\
\hline BYS & $6.84 \pm 0.08^{\mathrm{b}}$ & $1.16 \pm 0.01^{\mathrm{c}}$ & $3.35 \pm 0.05^{\mathrm{c}}$ & $0.99 \pm 0.01^{\mathrm{b}}$ & $7.76 \pm 0.01^{\mathrm{b}}$ & $78.08 \pm 0.15^{\mathrm{c}}$ & 373.51 \\
\hline MKL & $7.16 \pm 0.02^{\mathrm{a}}$ & $1.33 \pm 0.25^{\mathrm{b}}$ & $5.15 \pm 0.08^{\mathrm{b}}$ & $0.06 \pm 0.01^{\mathrm{d}}$ & $7.81 \pm 0.01^{\mathrm{a}}$ & $80.01 \pm 0.07^{\mathrm{b}}$ & 397.63 \\
\hline DST & $7.50 \pm 0.07^{\mathrm{c}}$ & $1.62 \pm 0.01^{\mathrm{a}}$ & $8.39 \pm 0.08^{\mathrm{a}}$ & $1.12 \pm 0.01^{\mathrm{a}}$ & $7.85 \pm 0.01^{\mathrm{a}}$ & $80.58 \pm 0.08^{\mathrm{a}}$ & 429.23 \\
\hline
\end{tabular}

Values are represented as mean \pm standard deviation in duplicate samples

FMX $=100 \%$ millet fura, BYC $=90 \%$ millet: $10 \%$ bambara nut, MKL $=80 \%$ Millet: $20 \%$ bambara nut, DST $=70 \%$ millet: $30 \%$ bambara nut.

Table 3. Functional properties of fura flour improved with bambara groundnut.

\begin{tabular}{|c|c|c|c|c|c|}
\hline & $\mathbf{p H}$ & Viscosity (cp) & Bulk density (g/ml) & WAC (\%) & Foaming (\%) \\
\hline FMX & $5.52 \pm 0.06^{\mathrm{b}}$ & $493.00 \pm 4.24^{\mathrm{a}}$ & $0.60 \pm 0.03^{\mathrm{c}}$ & $2.47 \pm 0.02^{\mathrm{a}}$ & $8.06 \pm 0.08^{\mathrm{d}}$ \\
\hline BYS & $6.14 \pm 0.01^{\mathrm{a}}$ & $378.50 \pm 4.95^{\mathrm{b}}$ & $0.64 \pm 0.00^{\mathrm{b}}$ & $1.75 \pm 0.01^{\mathrm{b}}$ & $10.08 \pm 0.11^{\mathrm{c}}$ \\
\hline MKL & $6.17 \pm 0.00^{\mathrm{a}}$ & $351.30 \pm 0.42^{\mathrm{b}}$ & $0.66 \pm 0.01^{\mathrm{a}}$ & $1.44 \pm 0.02^{\mathrm{b}}$ & $12.50 \pm 0.71^{\mathrm{b}}$ \\
\hline DST & $6.21 \pm 0.02^{\mathrm{a}}$ & $311.50 \pm 0.71^{\mathrm{c}}$ & $0.67 \pm 0.04^{\mathrm{a}}$ & $0.89 \pm 0.02^{\mathrm{c}}$ & $15.12 \pm 0.16^{\mathrm{a}}$ \\
\hline
\end{tabular}

Values are represented as Mean \pm Standard deviation in duplicate samples.

FMX $=100 \%$ millet fura, BYC: $90 \%$ millet: 10\% bambara nut, MKL $=80 \%$ millet: $20 \%$ bambara nut, DST $=70 \%$ millet: $30 \%$ bambara nut.WAC=Water absorption capacity

Table 4. Sensory evaluation of instant fura.

\begin{tabular}{|c|c|c|c|c|c|}
\hline Samples & Taste & Colours & Aroma & Mouthfeel & Overall acceptance \\
\hline FMX & $7.47 \pm 1.54^{\mathrm{b}}$ & $7.15 \pm 1.08^{\mathrm{a}}$ & $7.06 \pm 1.00^{\mathrm{a}}$ & $7.68 \pm 0.82^{\mathrm{a}}$ & $7.63 \pm 1.86^{\mathrm{a}}$ \\
\hline BYS & $6.84 \pm 1.19^{\mathrm{a}}$ & $7.08 \pm 1.11^{\mathrm{a}}$ & $6.89 \pm 1.66^{\mathrm{b}}$ & $6.68 \pm 1.20^{\mathrm{b}}$ & $7.10 \pm 1.24^{\mathrm{a}}$ \\
\hline MKL & $6.00 \pm 1.00^{\mathrm{b}}$ & $6.47 \pm 0.84^{\mathrm{b}}$ & $6.05 \pm 1.35^{\mathrm{b}}$ & $5.68 \pm 1.60^{\mathrm{c}}$ & $5.68 \pm 1.20^{\mathrm{b}}$ \\
\hline DST & $4.07 \pm 1.05^{\mathrm{c}}$ & $5.15 \pm 1.02^{\mathrm{c}}$ & $4.78 \pm 1.71^{\mathrm{c}}$ & $4.89 \pm 1.96^{\mathrm{d}}$ & $4.10 \pm 2.10^{\mathrm{c}}$ \\
\hline
\end{tabular}

Values are represented as mean \pm standard deviation in duplicate samples.

FMX $=100 \%$ millet fura, BYC $=90 \%$ millet: $10 \%$ bambara nut, MKL $=80 \%$ millet: $20 \%$ bambara nut, DST=70\% millet: $30 \%$ bambara nut.

has the highest scores than the other samples in terms of color, texture, aroma, taste and overall acceptability. Sample BYS has the second highest acceptability, followed by sample MKL. Sample DST was the least acceptable among the samples. Sample FMX also shows the highest acceptability in taste and aroma with mean values of $7.47 \pm 1.54$ and $7.06 \pm 1.00$ respectively, while sample DST has the least mean value of $4.07 \pm 1.05$, based on taste. Sample DST has the lowest aroma with the mean value of $4.78 \pm 1.71$.

The results of texture showed that there was no significant difference between sample FMX and BYS. The overall acceptability showed that 100\% (FMX) was most preferred followed by $90: 10$ $\%$ (BYS), 80:20\% (MKL) and 70:30\% (DST) with the following scores $7.63 \pm 1.86,7.10 \pm 1.24,5.68 \pm 1.20$ and $4.10 \pm 2.10$ respectively. There were no significant differences between $100 \%$ (FMX) and 90:10\% (BYS), but 70:30\% (DST) showed high significant difference when compared with other samples $(\mathrm{p}<0.05)$.

\section{Conclusion}

This study showed the effect of addition of bambara nut into millet-based fura. The addition of bambara nut improved the proximate, functional and sensory quality of millet-based fura. Nutritionally, the outcome of this study showed the products as alternative protein and energy source for infants and young children. Sample DST has the highest moisture content which might result to the growth of microorganisms and reduction of shelf-life of the product and sample FMX has the least moisture content which implies that it can stay longer that the rest of the samples. DST has the highest protein content, ash content and fat content which implies that it can be subjected to rancidity. The sensory qualities were significantly difference with addition of bambara nut flour. For BYS (90:10\% millet-based fura and bambara nut), the fura was generally acceptable, the pretreatment of bambara nut prior to usage could improve the colour, texture and water absorption capacity of the product. Bambara nut is a good source of protein which makes it desirable to complement other cereal foods.

\section{References}

[1]. Adebayo-Oyetoro AO, Ogundipe OO, Olatidoye OP, Abayomi HT. Nu- 
trient composition, functional and organoleptic properties of complementary food formulated from sorghum, walnut and ginger. J Agricul Technol. 2013;9(2):389-401.

[2]. Official Method of Analysis. Association of official analytical chemists, Arlington, V.A, U.S.A; 2005.

[3]. Baryeh EA. Physical properties of Bambara groundnuts. J Food Eng. 2001 Mar;47(4): 321-326.

[4]. Beuchat LR. Functional and electrophoretic characteristics of succinylated peanut flour protein. J Agric Fd Chem. 1977;25:258-261.

[5]. Duncan DB. New multiple range and multiple F tests. Biometrics. 1955 Mar; 11(1):1-11.

[6]. Dhingra S, Jood S. Organoleptic and nutritional evaluation of wheat bread supplemented with soybeans and barley flour. Food Chem. 2002;77(4):479488 .

[7]. Eltayeb ARSM, Ali AO, Abou-Arab AA, Abu-Salem FM. Chemical composition and functional properties of flour and protein isolate extracted from bambara groundnut (Vigna subterranea). Afr J Food Sci. 2011 Feb;5(2):8290.

[8]. Graham PH, Vance CP. Legumes: importance and constraints to greater use. Plant Physiology. 2003 Mar; 131:872-877.

[9]. Linnemann AR, Azam-Ali SN, Basu. Bambara groundnut (Vigna subterranea). JT Williams editior. Underutilised Crops. Pulses and Vegetables. Chap- man and Hall, London; 1994, 13-57.

[10]. Marero LM, Payumo EM, Librado EC, Lainez WN, Gopez MD, Homma S. Technology of using food formulations prepared from germinated cereals and legumes. J Food Sci. 1988 Sep;53(5):1391- 1395, 1455.

[11]. National Research Council. Lost Crops of Africa, Vol. II: Vegetables (Development, Security, and Cooperation Policy and Global Affairs). The Natl Academies Press, Washington DC.

[12]. Gopalan C, Deosthale YG, Rama sastri BV, Balasubramanian SC, Narasingha rao. Nutritive value of Indian Foods. National Institute of Nutrition, Hyderabad. 2015

[13]. Okaka JC, Ene GL. Food microbiology: method in food safety control. Enugu: Ocjanco Academic; 2005, 262.

[14]. Owusu-kwarteng J, Tano-debrah K, Glover R, Akabanda F. Process characteristics and microbiology of fura produced in Ghana. Nat Sci. 2010;8:289297.

[15]. Okpuzur J, Ogbunugafor HA, Okapor U, Sofidiya MO. Identification of protein types in bambara groundnut seeds: perspectives for dietary protein supply in developing countries. Excli J. 2010 Feb 1;9:17-28.

[16]. Oyeleke GO, Afolabi O, Ishola AD. Some quality characteristics and carbohydrate fractions of bambara groundnut seed flour. IOSR J Appl Chem. 2012 Oct;2(4):16-18. 